\title{
Platformsøkonomien og prekariatet
}

\author{
Stine Rasmussen \& Per Kongshøj Madsen
}

Denne artikel anlægger et arbejdsmarkedsperspektiv på det nye fænomen 'deleøkonomi' eller 'platformsøkonomi', som i artiklen anvendes som en mere retvisende term for fænomenet. Artiklens formål er dels at indkredse og beskrive, hvilke arbejdsrelaterede aktiviteter der findes i den fremvoksende platformsøkonomi i Danmark, dels at diskutere og vurdere, hvilke udfordringer der er ved platformsøkonomien, og hvordan den trækker nye og mere usikre ansættelsesformer med sig. Platformsøkonomien er i en dansk kontekst både teoretisk og empirisk et underbelyst område, hvilket begrunder artiklens eksplorative karakter.

\section{Deleøkonomi eller platforms- økonomi? - en begrebsdiskussion}

Fænomenet 'deleøkonomi' er i de senere år for alvor kommet på dagsordenen i Danmark, hvor både de trykte og elektroniske medier såvel som en række forskellige politiske aktører og interesseorganisationer i stigende grad bruger og udviser interesse for det. Eksempelvis så viser en simpel optælling på mediedatabasen Infomedia blandt 17 landsdækkende aviser, at begrebet deleøkonomi for første gang optræder i de trykte medier i første halvår af 2012. Brugen af begrebet tager for alvor fart fra og med andet halvår af 2014 (se figur 1). Det skyldes formentlig, at det er i efteråret 2014, at Uber gjorde sit indtog i Danmark. Efterfølgende har Uber fået meget mediedækning grundet uenighed om, hvorvidt der er tale om en samkørselsordning eller organiseret pirattaxakørsel. Betegnelsen platformsøkonomi er derimod stort set fraværende i medierne.

Også regeringen har udvist stor interesse for fænomenet deleøkonomi. Troels Lund Poulsen, der var Erhvervs- og Vækstmini- ster frem til november 2016, hvor den nye VLAK-regering blev en realitet, igangsatte en proces med at udarbejde en decideret strategi for deleøkonomien. Strategien skal handle om at styrke deleøkonomien, fordi den, som Troels Lund Poulsen udtaler "skaber vaekst og velstand i samfundet". Desuden skal den skabe klarere regler særligt i forhold til de forbrugere og virksomheder, der ønsker at benytte sig af de deleøkonomiske aktiviteter (Regeringen 2016, 37-38). Det er særligt skatteregler, der fokuseres på. Fagbevægelsen udviser også interesse for fænomenet, hvor eksempelvis LO har indtaget en mere kritisk position over for deleøkonomien. Deres bekymring går bl.a. på, om der opstår unfair konkurrence i visse brancher, og om de personer, der arbejder $\mathrm{i}$ deleøkonomien, har dårlige løn- og arbejdsvilkår og bliver "en slags moderne daglejere" uden beskyttelse og rettigheder (LO, 2016).

Bredt forstået så dækker deleøkonomi, som er den danske oversættelse af termen 'sharing economy', over en ny samfunds- 
Figur 1: Antal referencer til 'deleøkonomi' i 17 landsdoekkende dagblade fra 1. halvår 2012 til 1. halvår 2016.

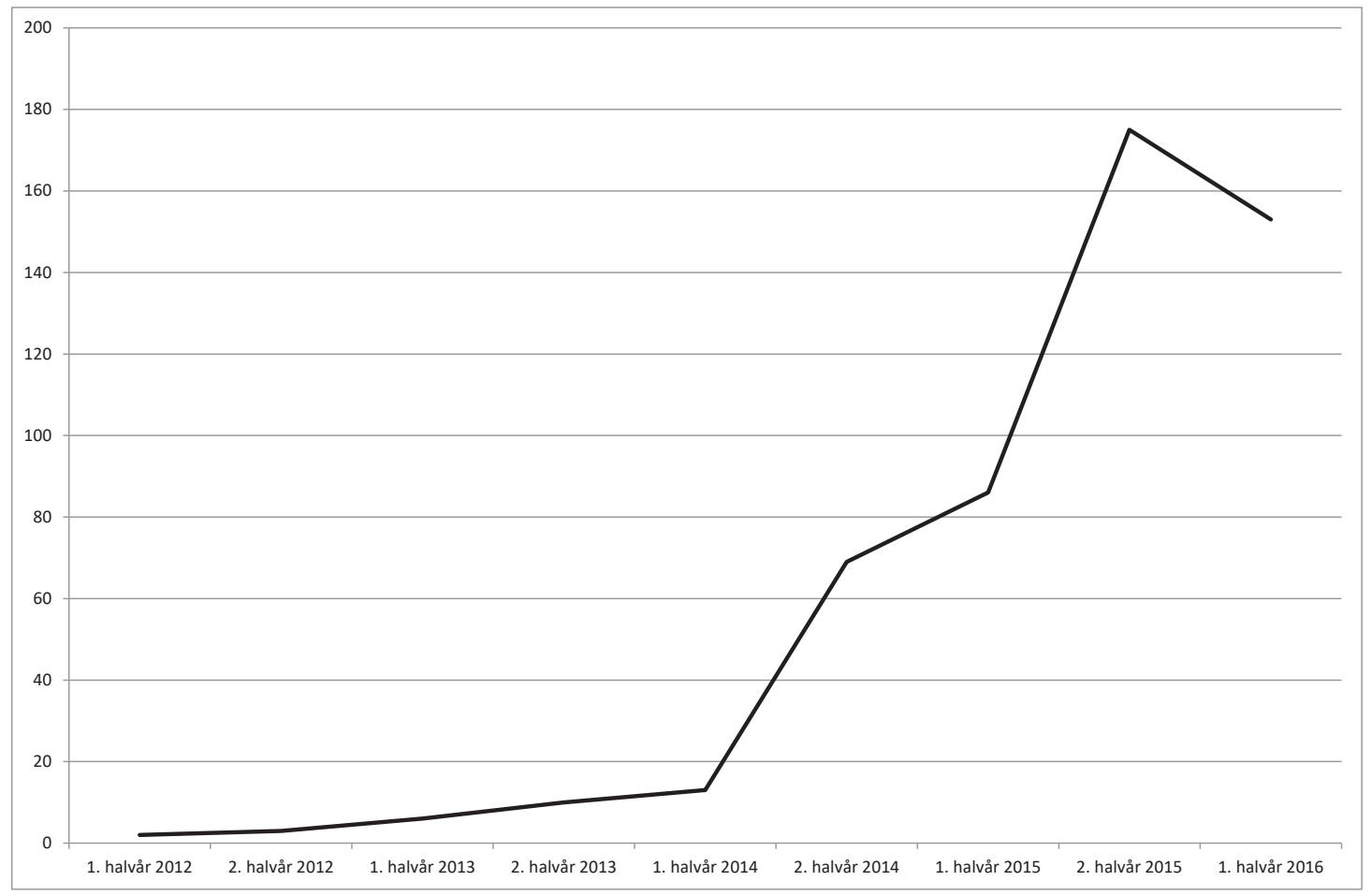

Kilde: Beregnet af forfatterne på baggrund af mediedatabasen Infomedia.

økonomisk trend, der ofte dateres til starten af 00'erne. Den består af forskellige forretningsmodeller, hvor adgangen til produkter, varer, tjenesteydelser og aktiviteter sker gennem deling fremfor ejerskab. Der er således tale om en ny måde at tænke økonomi og forbrug på. Rachel Botsman, der beskrev denne nye økonomi som et led i hendes bestræbelser på at forstå og begrebsliggøre nye tjenester og aktiviteter som $\mathrm{fx}$ Airbnb (privat boligudlejning), Zipcar (bildelingstjeneste), Netflix (streamingtjeneste) og eBay (e-handelssted med salg af nye og brugte varer) (Botsman, 2013), fremhæves ofte. Delingen kan finde sted fra virksomheder/organisationer til private, fra private til virksomheder/organisationer og fra private til private. Den kan have både monetære og ikke monetære formål, og kommercielle såvel som ikke kommercielle interesser (Dalberg Research, 2014). I sig selv indebærer sådanne former for fælles anvendelse af ressourcer ikke noget nyt. De historiske eksempler er talrige. Kolleger har kørt sammen til og fra arbejde. Plæneklipperen udlånes til naboen. En maskinstation sørger for høstarbejdet hos flere landbrug. Men det nye ved deleøkonomien er, at delingen sker systematisk, i stor skala og har digitale platforme som det væsentligste fundament, hvor platformene bruges til at skabe kontakt mellem dem, der ønsker at gøre brug af de deleøkonomiske aktiviteter og tjenester (Dalberg Research 2014; Service Cluster Denmark m.fl. 2015; Stokes m.fl. 2014). Samtidig er deleøkonomien karakteriseret ved store startomkostninger og små marginalomkostninger ved udvidelse af aktiviteten (Demary, 2014). Derfor er der en tendens til, at få store spillere kommer 
til at dominere. Der er således en parallel til de klassiske 'naturlige monopoler' inden for jernbanedrift og forsyningsvirksomheder (el, vand, kloak osv.).

I og med at deleøkonomi er karakteriseret ved fælles anvendelse af ressourcer, dækker den også over en stor mangfoldighed af aktiviteter, ydelser, tjenester osv. Som nævnt før kan så forskelligartede former for delinger som samkørsel og boligudlejning karakteres som en del af det deleøkonomiske felt, men inkluderet er fx også sådan noget som deling af redskaber, haver, fødevarer osv., udlån af penge samt deling af oplevelser, serviceydelser, kompetencer, viden og idéer. Nogle af de store og kendte internationale spillere er Uber og Airbnb, som vi også kender i en dansk sammenhæng. I Danmark forbindes deleøkonomi fx også med samkørseltjenesten GoMore, men dækker også over kjolebytning (ReSecond), abonnement på børnetøj (Vigga), fragt af genstande (Bringrs), leje af brugsgenstande (Jepti), udførelse af håndværksmæssige opgaver og andre serviceydelser som fx hundeluftning (AHandyHand og Helpfully) og fødevarefællesskaber. Den ret brede term deleøkonomi rummer derfor både aktiviteter, der kan karakteriseres som decideret salg af arbejdskraft (fx håndværksopgaver) såvel som over reel deling af materielle og ikke materielle ting (som fx deling af en kjole, en god idé eller værktøj). Som vi vender tilbage til i næste afsnit, afgrænser vi os i det følgende udelukkende til de aktiviteter i deleøkonomien, der involverer en form for betalt arbejdsindsats, og som derfor især er interessante $\mathrm{i}$ en arbejdsmarkedssammenhæng.

Deleøkonomi bliver ofte lanceret som et alternativ eller supplement til den eksisterende måde at købe og udveksle varer og tjenesteydelser på, hvor der bl.a. lægges vægt på, at almindelige borgerne får mulighed for at dele goder, oplevelser, evner m.v. med hinanden og for at få indflydelse på fx produktionen og skabelsesprocessen af forskellige varer og tjenesteydelser. Deleøkonomien italesættes også som en innovativ måde at tænke økonomi, ressourcer og fællesskab på, hvor både de individuelle og de kollektive ressourcer udnyttes bedre, og hvor de samfundsmæssige udfordringer derfor bedre kan håndteres (Dalberg Research 2014; Dagnino 2016, 1). Begrebet deleøkonomi giver derfor positive associationer.

Andre argumenterer dog for, at det er mere hensigtsmæssigt at bruge termen 'platform economy', som på dansk oversættes til 'platformsøkonomi' ud fra en betragtning om, at denne betegnelse opfattes mere neutral. Platformsøkonomi henviser derfor til de forretningsmodeller, der er vokset frem siden årtusindeskiftet og som har det til fælles, at digitale, ofte internetbaserede, platforme er mellemleddet mellem den, der ønsker at gøre bruge af en tjeneste, service eller aktivitet og den, der ejer den. ${ }^{1}$ I den forståelse dækker platformsøkonomi derfor over et stort antal digitale platforme, der eksempelvis både formidler arbejde, forskellige tjenesteydelser og services, redskaber, idéer m.v. (Kenny \& Zysman, 2015). LO, der som tidligere nævnt forholder sig mere kritisk til deleøkonomien, argumenterer da også for brugen af betegnelsen platformsøkonomi med den begrundelse, at mange af aktiviteterne er drevet af virksomheder, der er profitorienterede og ikke i sig selv er motiveret af ressourcemæssige eller sociale hensyn (LO, 2016) I denne artikel anvendes også begrebet platformsøkonomi frem for deleøkonomi ud fra en betragtning om, at fællestrækket ved aktiviteterne netop er brugen af digitale platforme. 


\section{Artiklens fokus og formål}

Som nævnt er aktiviteterne i platformsøkonomien mange og forskelligartede. I en arbejdsmarkedsrelateret sammenhæng er det imidlertid ikke samtlige, der er relevante. Vores fokus er på de platforme, der direkte involverer en form for arbejdskraft, hvor en person, organisation eller virksomhed efterspørger en service, en ydelse eller udførelse af et job til en vis sum penge, mens en anden byder ind, udfører opgaven og modtager betaling herfor. DeGroen og Maselli anvender termen 'online labour market' til at karakterisere denne del af arbejdsmarkedet og sætter det i modsætning til et 'offline labour market', hvor sidstnævnte er det traditionelle, velkendte arbejdsmarked, som typisk indbefatter en form for menneskelig kontakt eller relation mellem den, der efterspørger arbejdet, og den der udfører det. Omvendt udbydes og efterspørges arbejdskraften i denne del af platformsøkonomien gennem online kommunikation og kræver i nogle tilfælde slet ikke fysisk kontakt mellem aktørerne. (DeGroen \& Maselli, 2016). Andre som fx Huws m.fl. bruger termen 'crowd work' til at dække over den type arbejde, der finder sted på de digitale platforme i og med, at de forstår crowd work som "paid work that is organised by an online platform" (Huws m.fl. 2016, 2). Disse forståelser og definitioner tilslutter vi os. Set i det lys afgrænser vi os derfor også fra de aktiviteter i platformsøkonomien, der handler om at bytte eller dele varer eller tjenester, eksempelvis kjolebytning, fødevarefællesskaber og samkørsel, og fokuserer dermed udelukkende på de digitale platforme, hvor forskellige former for arbejdskraft udbydes og efterspørges. Det betyder eksempelvis, at vi ikke interesserer os for en tjeneste såsom GoMore, fordi konceptet er bygget op omkring samkørsel, hvor en person, der i forvejen skal køre en bestemt strækning, modtager betaling for at medtage en el- ler flere passagerer. Det samme gælder en tjeneste som Airbnb, hvor det ikke er en arbejdskraft, der købes men en eller flere overnatninger i et privat hjem, selv om der godt kan være forbundet en vis arbejdsindsats med udlejningen. Her betragter vi dog ikke den arbejdsindsats som den centrale for platformen.

En af de store udfordringer ved arbejdet i platformsøkonomien er, at aktiviteterne ikke er reguleret på samme måde som aktiviteterne på det etablerede, offline arbejdsmarked. Man kan i denne forbindelse stille spørgsmålet, om platformsøkonomien medfører, at der opstår en ny gruppe af mere løse ansættelsesformer, hvor enkeltindivider gør det til deres primære hovedindtægtskilde at byde ind på og udføre de forskellige opgaver, der efterspørges på de digitale platforme fremfor at have ét hovedjob hos en enkelt arbejdsgiver. Det gælder for eksempel den Uber-chauffør, der gør den private taxakørsel til en levevej, eller den håndværker, der byder ind på småopgaver hos private som den primære måde at sikre sig indtjening på. Sådanne måder at arbejde på har en vis lighed med det, vi i litteraturen om usikre eller prekære ansættelsesformer allerede kender som løsarbejdere, vikararbejdere eller som selvstændige uden ansatte, konsulenter eller freelancearbejdere, der arbejder på egen hånd, men hyres ind til forskellige større eller mindre opgaver. For disse grupper af atypisk ansatte viser den danske forskning bl.a., at der er øget usikkerhed om lønninger, lavere timeantal, færre rettigheder i ansættelsesforholdet og begrænset adgang til social beskyttelse (Andersen \& Karkov 2011; Larsen \& Navrbjerg 2011; Rasmussen m.fl. 2016; Scheuer 2011).

På den baggrund er formålet med denne artikel derfor at belyse, hvilke former for arbejde, der udbydes og efterspørges i den danske platformsøkonomi, herunder hvilke løn- og ansættelsesvilkår, der arbej- 
des under, og hvilke sociale rettigheder, der tilbydes eller ikke tilbydes. Vi ønsker ydermere at diskutere, hvilke udfordringer der er ved denne nye arbejdsform og søge at vurdere, i hvilket omfang platformsøkonomien trækker nye usikre ansættelsesformer med sig. Afslutningsvis ser vi også på de positioner, som centrale aktører på arbejdsmarkedet har taget i forhold til platformsøkonomien med henblik på at kortlægge de politiske strategier, der kan komme i spil i de kommende år.

I det følgende præsenteres først artiklens analyseramme. Derefter gives en beskrivelse af det metodiske og empiriske grundlag, som artiklen hviler på. Det leder over til en nærmere redegørelse for det arbejde, der finder sted i den danske platformsøkonomi med fokus på løn, ansættelsesvilkår og sociale rettigheder. Herefter følger en diskussion og vurdering af udfordringerne og usikkerheden ved disse nye måder at arbejde på. Platformsøkonomien er både teoretisk og empirisk et underbelyst område i Danmark, hvilket begrunder artiklens eksplorative og til tider beskrivende karakter.

\section{Kilder til prekarisering - Analyseramme}

Der findes en omfattende international litteratur, der beskæftiger sig med usikre måder at arbejde på samt konsekvenserne heraf og som går under forskellige betegnelser som fx 'vulnerable work', 'non standard employment', 'flexible employment' 'atypical employment' osv. (for overblik over de forskellige definitioner se Kalleberg,2000). På trods af forskellige måder at benævne dette arbejde på, er fællestrækket ved denne litteratur, at der fokuseres på arbejde, som afviger fra standardarbejdet, der ofte forstås som et fuldtidsarbejde $i$ en tidsubegrænset ansættelse og som udføres på et bestemt ansættelsessted. Det kan fx dreje sig om deltidsarbejde, vikararbejde, tidsbegrænsede ansættelser, løsarbejde, freelancearbejde osv. (Kalleberg, 2000). I de senere år er det dog særligt termen 'prekariatet', der er kommet på dagsordenen, bl.a. i forhold til at forstå usikre ansættelsesformer og konsekvenserne heraf. Det skyldes i høj grad den britiske professor Guy Standing, der har udgivet flere værker, hvori han argumenterer for fremvæksten af et globalt prekariat, der skal forstås som en ny socialgruppe eller klasse i samfundet, som på et mere generelt plan befinder sig en usikker situation (Standing 2011; Standing 2014). Prekariatet udgør ifølge Standing en ny "dangerous class" uden et "anchor of stability" (Standing 2011, 1). Standing er dog ikke ophavsmanden til begrebet, der kan spores tilbage til franske sociologer i 1980'erne, som anvendte det i beskrivelsen af visse former for usikkert arbejde (Standing 2011, 15). I denne artikel anvender vi Standings forståelse af prekariatet, selv om andre dele af litteraturen om usikre ansættelsesformer selvfølgelig også er relevant.

Prekariatet er ifølge Standing en heterogen gruppe. Den består af arbejdsløse, sygdomsramte og af dem, der arbejder, i fx midlertidige og mere flygtige ansættelser, deltidsarbejdere, personer der arbejder på egen hånd (freelancere, selvstændige uden ansatte m.v.), praktikanter, migrantarbejdere og enlige mødre i lavindkomstjobs. Fællestrækket ved de persongrupper, der er beskæftigede, er, at arbejdet ikke er stabilt eller sikkert. Man arbejder for at leve eller overleve, og man tager det arbejde, det er muligt at få (Standing 2011, 23). Man har derfor ikke en "occupational identity", altså en form for fagidentitet, og ens arbejde er karriereløst (Standing 2011, kapitel 1). Det er dog ikke så meget typen af ansættelse, der definerer, om man er en del af prekariatet eller ej. En deltidsansættelse eller midlertidig ansættelse behøver i sig selv ikke at 
medføre, at man befinder sig i en usikker situation. Men denne måde at arbejde på bliver prekær, hvis den ikke giver individet mulighed for at opbygge en karriere eller en arbejdsidentitet (Standing 2011, 27), og derved gør arbejdet uønsket at være i. Standing argumenterer videre for, at det at befinde sig i prekariatet betyder, at man oplever vrede, en tilstand af anomi, angst og fremmedgørelse (Standing 2011,33-41).

Standing bruger også termen 'denizens' til at pointere, at det at tilhøre prekariatet betyder, at man har færre rettigheder, end hvis man var en 'citizen'. På dansk kan det oversættes til at være en beboer eller indbygger frem for en samfunds- eller medborger med et fuldt sæt af rettigheder. Rettighederne, som prekariatet mangler eller har begrænset adgang til, vedrører mange forskellige sfærer af livet. De kan være alt fra manglende eller begrænset ret til at stemme, manglende mulighed for at deltage i det kulturelle liv, manglende rettigheder og beskyttelse i ansættelsesforholdet eller mindre adgang til social beskyttelse $\mathrm{fx}$ i form af pension eller adgang til sundhedsvæsenet (Standing 2011, 23).

I relation til denne artikels fokus så er det ikke så meget fremvæksten af en ny klasse, der er central. Men der er elementer ved Standings beskrivelse af prekariatet, som vi anser som anvendelige til at forstå, hvorvidt platformsøkonomien trækker nye usikre ansættelsesformer med sig. I og med at vi ikke har haft mulighed for at undersøge folks opfattelse af at arbejde i platformsøkonomien, kan vi ikke afdække - set fra arbejdstagerens synspunkt - om arbejdet er karriereløst og uden fagidentitet, hvilket er centrale pointer hos Standing. Men vi kan, med afsæt i Standings forståelse, undersøge, om arbejdet i platformsøkonomien giver mere usikkerhed fx i form af lav løn, færre rettigheder og mindre social beskyttelse end det, vi kender fra det etablerede arbejdsmarked. Er det fx sådan, at det arbejde, der tilbydes på de digitale platforme, generelt lønnes lavere? Er det småopgaver med få timer eller længerevarende jobs? Og hvad har man som arbejdstager af rettigheder og beskyttelse i ansættelsesforholdet, når man udfører opgaver i platformsøkonomien? Dette er nogle af de spørgsmål, vi adresserer i artiklen.

\section{Eksisterende forskning og empirisk grundlag}

Fordi platformsøkonomien er et relativt nyt fænomen i en dansk sammenhæng, er der fortsat meget lidt viden om fænomenet i en dansk kontekst. Det gælder eksempelvis i forhold til, hvor udbredt det er at arbejde i platformsøkonomien, hvem der gør det, eller hvor stor en del af beskæftigelsen, som platformsøkonomien udgør. Samtidig er det vanskeligt at indfange denne type arbejde gennem de officielle arbejdsmarkedsstatistikker, ligesom platformene ikke nødvendigvis selv skilter med omfanget af deres jobs og brugergrupper.

Der findes nogle få udenlandske studier, der har forsøgt at kortlægge omfanget af arbejdet i platformsøkonomien i andre lande. Fx viser de såkaldte 'Crowd Working Surveys', der er udført i henholdsvis England, Sverige, Holland, Østrig og Tyskland, at mellem 9 og $19 \%$ af befolkningerne har udført arbejde, som de har fået gennem digitale platforme. For mange lader onlinearbejdet dog mest til at være sporadisk, idet kun mellem 5 og $9 \%$ har svaret, at de udfører arbejde gennem platformene på ugentlig basis (Huws m.fl. 2016, 23-27). Undersøgelserne viser også, at lønnen, der tjenes på platformene, langt overvejende udgør et mindre supplement til ens indkomst, og kun for 2-3\% udgør betalingen fra platformene mere end halvdelen af indkomsten (Huws m.fl. 2016, ii). Et lidt overraskende 
resultat er også, at de, der anvender platformene mest, søger efter og tager mange forskellige former for arbejde fremfor kun at søge efter én type af arbejde (Huws m.fl. 2016, 30-31). Det kan tolkes som et tegn på, at arbejdstagerne i onlinearbejdet er mindre kritiske overfor typen af arbejde, der udføres, og at der er en vis 'desperation' i onlinearbejdet, som mest handler om at sikre sig en indtjening af betydning (Huws m.fl. 2016, 31).

I en nordisk kontekst er Norge længst med at undersøge platformsøkonomiens udbredelse og karakteristika. Fx har et større norsk studie fra 2016 bestående af både spørgeskemaundersøgelser, kvalitative interviews og dokumentstudier identificeret knap 30 arbejdsrelaterede platforme i Norge (Jesnes m.fl. 2016, 22). $16 \%$ af befolkningen er registreret på de digitale platforme enten som efterspørgere eller udbydere af arbejdskraft, men maksimalt $10 \%$ af befolkningen over 18 har udført arbejdet via platformene og kun ganske få (omkring 2 \%) gør det på ugentlig basis (Jesnes m.fl. 2016, 22-28), hvilket er i tråd med de førnævnte Crowd Working Surveys. Cirka 7 \% af de norske virksomheder med minimum 5 ansatte har anvendt platformene som et led i at rekruttere arbejdskraft (Jesnes m.fl. 2016, 26).

Den eksisterende viden i dansk sammenhæng begrænser sig til nogle få mindre spørgeskemaundersøgelser fra analyseinstitutter, tænketanke og interesseorganisationer af hvem og hvor mange, der har anvendt tjenester eller aktiviteter i platformsøkonomien. ${ }^{2}$ Her spørges der dog mere bredt og ikke kun til de tjenester, der handler om arbejdskraft. Typisk er fokus på brugen af Airbnb, Uber eller GoMore, der er de mest kendte og udbredte i Danmark. Disse undersøgelser viser, at cirka $10 \%$ af befolkningen har erfaringer med at bruge disse aktiviteter. Andelen har været stigende i de senere år, og unge og personer bosat i hovedstaden er mest tilbøjelige til at benytte sig af dem (Munkøe m.fl. 2015; Nordea 2016). Disse resultater er overensstemmende med fund i de førnævnte udenlandske studier. Studierne siger imidlertid ikke meget om, hvem der arbejder i platformsøkonomien, men belyser mere generelt, hvem der anvender aktiviteterne og tjenesterne både som forbrugere og udbydere.

På grund af den begrænsede viden om online arbejdsmarkedet i Danmark har denne artikel en mere eksplorativ karakter. Vi forsøger at skabe overblik over de digitale platforme, der er rettet mod at udbyde og efterspørge arbejde i en dansk sammenhæng, de arbejdsopgaver, der tilbydes, de persongrupper, der udbyder deres arbejdskraft og de vilkår, som arbejdet forgår under. Denne viden bruges som afsæt for efterfølgende vurdering og diskussion. Empirien er baseret på viden fra et endnu upubliceret notat om den danske platformsøkonomi (Rasmussen \& Madsen, 2016), som forfatterne har udarbejdet til et nordisk pilotprojekt finansieret af Nordisk Ministerråd og med deltagelse af forskere fra Danmark, Sverige, Norge, Finland og Island. I pilotprojektet foregik empiriindsamlingen gennem en gennemgang af den eksisterende viden på området frem for en selvstændig empiriindsamling. Det har inden for projektets rammer ikke været muligt at foretage interviews eller lave spørgeskemaundersøgelser med de personer, der udbyder og efterspørger arbejde på platformene. Vi har i stedet søgt at identificere de digitale platforme i Danmark, der udbyder og efterspørger arbejdskraft og derefter indhente viden fra dem. Vores fremgangsmåde har bestået $\mathrm{i}$ at identificere og gennemlæse relevante hjemmesider, der er hjemsted for de digitale platforme. Den viden har vi brugt til at beskrive platformene samt det arbejde, der udbydes og efterspørges. Som 
et led $\mathrm{i}$ identifikationen af de digitale platforme har vi bl.a. støttet os til, hvad der i den eksisterende litteratur allerede er udpeget som arbejdsrelaterede digitale platforme, ligesom vi har foretaget søgninger af mediernes omtale af platformene og selv fremsøgt platformene gennem internetsøgninger. Vi har, som tidligere nævnt, kun valgt de arbejdsmarkedsrettede platforme ud, dvs. dem hvor det er en arbejdsindsats, der udbydes og efterspørges. ${ }^{3}$

\section{Arbejdet i platformsøkonomien - et overblik og en beskrivelse}

Gennem søgninger i sommeren, efteråret og vinteren 2016 har vi i alt identificeret i cirka 10 platforme, hvor der udbydes og efterspørges arbejdskraft, samtidig med at de i en eller anden udstrækning, men ikke nødvendigvis udelukkende, er rettet mod dansk arbejdskraft. Vi kan dog ikke være sikre på, at de fundne platforme udgør et fuldstændigt udtømmende billede, da nye platforme hurtigt kan opstå, mens andre kan forsvinde eller forandre sig.

Det arbejde, som vi har identificeret på disse platforme, kan forstås ud fra to forskellige parametre (DeGroen \& Maselli 2016; DeGroen m.fl. 2016). For det første kan man skelne mellem, om arbejdet er lokalt forankret og kræver en fysisk tilstedevæ- relse (fx hundeluftning eller håndværksarbejde), eller om arbejdet kan udføres virtuelt og dermed har en mere global karakter, hvor den der udfører opgaven kan befinde sig hvor som helst (fx en oversættelsesopgave). For det andet kan arbejdet beskrives ud fra hvilke niveauer af færdigheder eller kompetencer, det kræver. Er der fx tale om ufaglært arbejde, som mange kan udføre, eller er der snarere tale om en arbejdsopgave, der kræver særlig viden eller kompetence? Tabel 1 illustrerer disse parametre og kombinationer heraf og giver eksempler på typer af arbejdskraft samt typer af platforme, der formidler arbejdet.

Som tabellen illustrerer nederst i højre hjørne, er der identificeret flest platforme, der er rettet mod mindre specialiseret arbejdskraft og som samtidig kræver lokal tilstedeværelse for at løse opgaven. Det kan være udførelse af mindre håndværksmæssige opgaver (fx udskiftning af et vindue eller rensning af et nedløbsrør), malerarbejde, flyttearbejde, havearbejde, hundeluftning, kattepasning, børnepasning osv. Platforme såsom Meploy, DenLilleTjeneste, AHandyHand, Helpfully og Lejdet er eksempler herpå, men nogle af dem indeholder dog også opgaver, der kan placeres andre steder i oversigten. Eksempelvis efterspørges og tilbydes der på nogle platforme undervis-

Tabel 1: Oversigt over typer af platformsøkonomiske aktiviteter med formidling af arbejdskraft i Danmark

\begin{tabular}{l|l|l} 
& Virtuel/global & Lokal/fysisk \\
& $\begin{array}{l}\text { Oversættelse, programmering, } \\
\text { Mellem til høj specialiseret viden }\end{array}$ & Undervisning, behandling \\
& $\begin{array}{l}\text { Eks. på platforme: Upwork, } \\
\text { Freelancer.com, Fiverr, Guru.com }\end{array}$ & \\
\hline $\begin{array}{l}\text { Ingen eller mindre specialiseret } \\
\text { viden }\end{array}$ & Transskribering, informationsindsamling & $\begin{array}{l}\text { Håndværksarbejde, hundeluftning, havear- } \\
\text { bejde, taxakørsel, rengøring }\end{array}$ \\
& $\begin{array}{l}\text { Eks. på platforme: Uber, MePloy, DenLilleTje- } \\
\text { neste AHandyHand, Helpfully, Lejdet }\end{array}$
\end{tabular}

Kilde: udarbejdet af forfatterne med inspiration fra De Groen \& Maselli (2016) og De Groen m.fl. (2016). 
nings- eller behandlingshjælp, som kræver fysisk tilstedeværelse, men et højere kompetenceniveau end eksempelvis hundeluftning. Langt størsteparten af opgaverne på disse platforme har dog karakter af forefaldende småopgaver, der ikke kræver lang uddannelse eller meget specifikke færdigheder. At denne type arbejde dominerer på platformene findes også i udenlandske studier (DeGroen m.fl., 2016).

Går vi lidt tættere på disse platforme, beskriver MePloy sig fx som et "supplement til det eksisterende jobmarked" rettet mod unge og studerende. Her kan både enkeltpersoner og virksomheder oprette et såkaldt 'ploy', som er en beskrivelse af den opgave, der ønskes udført, og derefter kan der bydes ind på opgaven. Den, der efterspørger en opgave, vælger så et af tilbuddene, og der indgås en aftale. Opgaverne skal kunne løses på mellem 1 og 7 timer, og timelønnen er fast på $150 \mathrm{kr}$. i timen. Betalingen sker digitalt (gennem en app), hvor firmaet bag platformen modtager $5 \%$ af opgaveprisen. Efterfølgende laves en rating af den, der udførte arbejdet, som andre kan læse. De andre nævnte platforme ligner Meploy, men med mindre variationer. Eksempelvis er der på flere af de andre platforme ikke en maksimumsgrænse for antallet af timer, som en opgave må tage, ligesom der kan være lidt variation i priserne for opgaverne. På AHandyHand er lønniveauet eksempelvis på mellem $60 \mathrm{og} 100 \mathrm{kr}$. for personer under 18 og mellem 100 og 300 kr. for personer over 18. På DenLilleTjeneste ligger lønniveauet også mellem 100 og 300 kr. På de fleste platforme kræver firmaet bag en vis procentdel af opgaveprisen (typisk mellem 5 og $20 \%$ ), som skal trækkes fra for at få den reelle pris på opgaven. Lønnen eller opgaveprisen er det eneste, platformene vejleder i. Alt andet, der vedrører arbejdets udførelse, er op til parterne selv at aftale.

Det er uklart, hvor udbredt det er at tage arbejde på disse platforme, men en søgning på antallet af ploys på MePloy i december 2016 viste, at der var under 10, hvilket ikke tyder på den store udbredelse. Stifteren af konceptet har dog i en artikel fra maj 2016 udtalt, at over 1000 er tilmeldt på hjemmesiden (Jørgensen, 2016). På AHandyHand tilbyder cirka 6000 personer deres arbejdskraft, og på Helpfully er antallet omkring 5000. Det har ikke været muligt at præcisere antallet på DenLilleTjeneste, men de fremhæver selv på hjemmesiden, at de har formidlet mere end 1000 opgaver. I december 2016 var der cirka 20 åbne opgaver.

Uber er en anden platformsøkonomisk tjeneste, der falder i samme kategori, idet arbejdet udføres lokalt og ikke kræver et højt specialiseringsniveau. Denne tjeneste gjorde sit indtog på det danske arbejdsmarked i november 2014. Den findes dog fortsat kun i København, og Uber er en tjeneste, hvor man kan bestille og betale en transportydelse gennem en app. Det er almindelige danskere, der kan tilmelde sig og køre som Uber-chauffører ved brug af egen bil. Forudsætningen er derfor kun et kørekort, en vis køreerfaring (kørekørt i minimum et år) og en vis alder (mindst 21 år). Desuden tjekker Uber straffeattesten. Uber fungerer på den måde, at ønsker man at blive kørt fra A til B, så bestiller man en tur gennem Ubers app. Uber-chauffører i området kan så acceptere anmodningen, hvorefter kunden får information om, hvornår chaufføren ankommer, og hvem chaufføren er. Når turen er afsluttet, sker betalingen gennem et betalingssystem i app'en. Kunden skal rate chaufføren og turen fra 1 til 5 stjerner. Uber tager et servicegebyr på omkring $20 \%$ af indtægten. Der er cirka 1700 registrerede Uber-chauffører i København (Christiansen, 2016). Chaufførerne indgår en 'partneraftale' med Uber, der definerer chaufførens forpligtigelser og rettigheder. Aftalen fremhæver eksplicit, at der ikke er tale om 
en ansættelsesaftale, men en samarbejdsaftale, hvor Uber i øvrigt er repræsenteret af en virksomhed registreret i Holland.

Uber er klart den platformøkonomiske aktivitet i Danmark, der har fået mest opmærksomhed i den offentlige debat og blandt politiske aktører, fordi det er uklart, hvorvidt det er en samkørselordning eller decideret taxakørsel på linje med den etablerede og regulerede taxakørsel i Danmark. Taxabranchen og andre dele af den danske fagbevægelse har protesteret mod Uber og hævder, at det er pirattaxakørsel og argumenterer for, at Uber-kørslen er konkurrenceforvridende og med til at underminere taxabranchen. I sommeren 2016 blev et mindre antal Uber-chauffører dømt for at bedrive ulovlig taxakørsel og idømt bødestraf. Siden har anklagemyndigheden ved Københavns Politi i december 2016 rejst tiltale mod det hollandske selskab, der står bag Ubers danske aktiviteter. Indtil videre kører Uber-chaufførerne fortsat i København.

I øverste venstre hjørne af tabel 1 findes en anden type beskæftigelse i den danske platformsøkonomi. Det er arbejde, der ikke kræver lokal eller fysisk tilstedeværelse et bestemt sted, når opgaven skal løses, men som kan løses hjemme hos opgaveløseren selv og som samtidig kræver et vist færdighedsniveau og fagkendskab. Det kan eksempelvis dreje sig om skrive- og oversættelsesopgaver, programmering, softwareudvikling, designopgaver, grafisk arbejde og andet IT-arbejde. Det er kendetegnende for de platforme, vi har identificeret, at de ikke udelukkende opererer i en dansk kontekst, men netop henvender sig til et internationalt publikum i og med at opgaverne kan løses hvor som helst. Upwork, Freelancer. com, Fiverr og Guru.com er eksempler på platforme, hvor vi har identificeret danske brugere, der tilbyder deres arbejdskraft. På Freelancer.com har vi eksempelvis i decem- ber 2016 identificeret cirka 400 danske brugere, men det vides ikke, hvor mange der reelt har udført opgaver gennem platformen. Tænketanken CEVEA har lavet en undersøgelse af Upwork, som er den største digitale jobbørs i verden, når der måles på antallet af arbejdsopgaver, der bliver udført på årlig basis (CEVEA 2015, 40). Upwork er bl.a. rettet mod IT-arbejde, som fx programmering og softwareudvikling, men favner fx også juridisk assistance, design- og skriveopgaver, salgsopgaver, ingeniørarbejde og andet konsulentarbejde. Ifølge CEVEA's undersøgelse var cirka 1600 danske freelancere tilknyttet Upwork i 2015, og 163 af disse havde udført arbejdsopgaver gennem Upwork (CEVEA 2015, 41). Studiet viser også, at langt størsteparten af det arbejde, der udbydes på Upwork, er deltidsarbejde (78 \%). Længden af arbejdskontrakterne varierer noget. En tredjedel af det udbudte arbejde er kontrakter med en længde på mere end 6 måneder, $27 \%$ er arbejdsopgaver, det typisk tager nogle måneder at løse, $15 \%$ tager uger at løse, og $23 \%$ er arbejdsopgaver, der kan løses på timer eller dage (CEVEA 2015, 43). CEVEA har også undersøgt timelønnen for de danskere, der har udført arbejdsopgaver gennem Upwork og finder, at der er en relativ stor lønspredning. Naturligt nok varierer timelønnen meget alt efter hvilken arbejdsopgave, der løses, hvor timelønnen er højest for software- og marketingsopgaver (cirka $300 \mathrm{kr}$. i timen) og lavest for skrive- og oversætterarbejde (omkring 100 kr. i timen). Den hyppigst forekommende timeløn er på 100-150 kr. (CEVEA 2015, 45-46). 10 \% af lønnen går dog til Upwork, og der udbetales ikke andre goder som fx feriepenge eller pension udover timelønnen, hvilket også er tilfældet på de tidligere nævnte platforme.

Den sidste kategori i tabel 1 - globalt/ virtuelt arbejde med lille eller ingen grad af kompetencer - har vi ikke fundet dan- 
ske eksempler på, men en platform som Amazon Mechanical Turk kan placeres i denne kategori. Her er det fx muligt at udføre transskriberingsopgaver og informationssøgningsopgaver, som stort set alle kan løse. Det er muligt, der er danske brugere tilknyttet denne platform, men de har ikke været mulige at identificere.

\section{Er arbejdet i platformsøkonomien prekært?}

At arbejde i platformsøkonomien behøver ikke pr. automatik være usikkert. Men ofte er det uklart, om der udføres et reelt arbejde, som den der finder sted på det etablerede arbejdsmarked, eller om man netop blot deler eller udveksler ydelser eller produkter. Derfor, kan man forestille sig, at der kan opstå større problemer i relation til individets rettigheder, beskyttelse osv. I en international sammenhæng fremhæves derfor ofte risikoen for, at platformsøkonomien skaber en gruppe af løst ansatte med ringere arbejds- og ansættelsesvilkår, svingende indtjening m.v. (se fx Dokko m.fl. 2015; Kenny $\&$ Zysman 2015).

Arbejdsforholdet i platformsøkonomien omfatter typisk tre aktører: bestilleren (kunden), udføreren (den beskæftigede) og platformen, som formidler arbejdsopgaven. Det fundamentale spørgsmål i forhold til både offentlig regulering og overenskomster er naturligvis, om platformen har en arbejdsgiverfunktion i forhold til udføreren, eller om udføreren opfattes som en selvstændig erhvervsdrivende, der løser en opgave for bestilleren, og hvor platformen blot fungerer som formidler. Både forholdet til offentlig regulering ( $\mathrm{fx}$ funktionærloven, ferieloven og skattelovgivningen) og til overenskomstsystemet vil afhænge af besvarelsen af dette spørgsmål. Problemstillingen er dog i sig selv ikke ny. På beskatningsområdet findes allerede en række kriterier for, om en person opfattes som en selvstændig erhvervsdrivende, en freelancer eller en lønmodtager. Disse forhold har betydning for de typer af udgifter, der kan fratrækkes i bruttoindkomsten og for betaling af arbejdsgiverafgifter og moms. Tilsvarende er der inden for det fagretlige system udviklet normer for en sondring mellem egentlig selvstændig virksomhed og såkaldte 'arme- og benvirksomheder', der opfattes som maskerede lønarbejdere. Eksempelvis lægger overenskomsterne på bygge- og anlægsområdet begrænsninger på arbejdsgivernes brug af selvstændige uden ansatte (BAT-kartellet, 2004).

De vigtigste kriterier på begge områder er, om arbejdet udføres under individuel instruktion og med en fast aflønning, eller om udføreren selv bærer en økonomisk risiko, medbringer egne redskaber og udfører opgaven for forskellige bestillere. Disse i sig selv velkendte forhold har netop været omdrejningspunktet for en række af de tvister, som er opstået i kølvandet på fremvæksten af platformsøkonomien. Eksemplet med Uber-chaufførerne illustrerer klart problemstillingen. Partner-kontrakten rummer en række individuelle forpligtigelser for chaufføren, ligesom betalingen for arbejdet formidles gennem Uber. På den anden side er chaufføren ikke garanteret en bestemt indtægt og bærer selv omkostningerne ved driften af arbejdsredskabet (bilen). Uber og de andre platforme, som formidler arbejdsopgaver, udnytter systematisk denne velkendte juridiske gråzone mellem lønarbejde og andre former for beskæftigelse til at udvikle deres forretningskoncepter.

Men hvis man anlægger en arbejdsmarkedssynsvinkel, er der er ikke tvivl om, at det arbejde, som formidles gennem de forskellige platforme, må betegnes som prekært i den forstand, at der er tale om løn- og arbejdsvilkår, der er ringere end forholdene på det regulerede arbejdsmarked. Typisk 
er de beskæftigede ikke garanteret arbejde af et bestemt omfang, men fungerer som daglejere, hvor arbejdsomfanget bestemmes af den aktuelle efterspørgsel efter deres arbejdskraft. Aflønningen er også gennemgående lav. Sammenlignet med mindstelønssatsen i kollektive overenskomster på ca. $120 \mathrm{kr}$. i timen er de ovenfor citerede timelønninger på platformene måske ikke helt ude af trit. Men vurderingen skal også ses i lyset af, at den gennemsnitlige samlede timefortjeneste for ufaglærte voksne arbejdere, ifølge Danmarks Statistiks lønstatistik (statistikbanken.dk), er betydeligt højere end mindstelønsatserne - omkring $240 \mathrm{kr}$. i timen. Hertil kommer, som allerede bemærket, at de beskæftigede i platformsøkonomien typisk ikke har ret til løn under sygdom, feriebetaling eller pension.

Disse spørgsmål har naturligvis været i den politiske fokus. I det følgende afsnit diskuteres derfor reaktionerne fra de danske fagforeninger og andre politiske aktører.

\section{De arbejdsmarkedspolitiske aktører og platformøkonomien}

I dette afsnit ser vi på de holdninger og politikker, der forelægges af de vigtigste politiske aktører som svar på væksten i platformsøkonomien.

\section{LO}

I maj 2016 offentliggjorde LO en rapport med fokus på de udfordringer, som platformsøkonomien rejser, og den strategi, der skal forfølges i relation hertil (LO, 2016). I rapporten diskuterer LO først en række begrebsmæssige spørgsmål i lighed med drøftelserne i den første del af denne artikel. Som allerede nævnt er det vigtigt for LO at skelne mellem begreberne deleøkonomi og platformsøkonomi. Her bør deleøkonomi generelt bruges om almennyttige aktiviteter som samkørsel, genbrug o.l. Derimod bør begrebet platformsøkonomi anvendes til at beskrive profitsøgende virksomheder, hvis forretningsmodeller er baseret på digitale platforme. Også platformsbaserede virksomheder bør hilses velkommen, men kun hvis de opererer i overensstemmelse med dansk lovgivning og den danske arbejdsmarkedsmodel.

Desuden påpeger LO nødvendigheden af at skelne mellem forretningsmodeller baseret på peer-to-peer-interaktion og virksomhed-til-kunde-interaktion. I det første tilfælde forbinder den digitale platform individuelle sælgere og købere af varer eller tjenesteydelser. Airbnb er et eksempel på en profitsøgende forretning baseret på denne model. I den anden model benytter et enkelt firma platformen til at forbinde sig flere forbrugere. Bildeling-virksomheden Car2Go, som opererede i Danmark i 2014-16, er et eksempel på denne forretningsmodel.

Sondringen mellem peer-to-peer-modeller og virksomhed-til-forbruger-modeller er dog ikke entydig. For eksempel kan Uber ses som repræsentant for begge forretningsmodeller afhængigt af, om man betragter de enkelte chauffører som ansatte hos Uber eller som privatpersoner, der tilbyder delebiltjenester. I de forskellige juridiske søgsmål mod Uber og Uber-chaufførerne er valget mellem disse to perspektiver naturligvis et centralt spørgsmål.

I sin diskussion af konsekvenserne af platformsøkonomien fokuserer LO ikke overraskende på de platforme, som direkte involverer beskæftigelse. Her identificeres en række udfordringer (LO 2016, 14-21):

- Manglende implementering af gældende lovgivning for eksempel med hensyn til sikkerhed på arbejdspladsen, ofte fordi den eksisterende lovgivning ikke er tilpasset til brugen af digitale platforme.

- Skatteunddragelse. 
- Manglende overholdelse af regler vedrørende forsikring, autorisation mv.

- Mangel på grundlæggende rettigheder for medarbejdere såsom sygedagpenge, betalt ferie etc. Dette er relateret til den uklare status af de involverede personer som enten ansatte eller selvstændige/freelancere.

På den baggrund foreslår LO både bedre implementering af eksisterende lovgivning og en række nye initiativer. Desuden diskuteres behovet for, at fagforeningerne udvider deres aktivitetsområde til at inddrage medarbejdere og selvstændige/freelancere i platformsøkonomien. Samtidig erkendes det, at der vil være barrierer herfor, fordi de beskæftigede i platformsøkonomien for det meste arbejder adskilt fra hinanden og uden en følelse af fælles faglig identitet.

Afslutningsvis skal det nævnes, at også en række andre faglige organisationer har forholdt sig til platformsøkonomiens fremvækst. Det gælder for eksempel HK Privat, 3F, Teknisk Landsforbund og Prosa. Således har 3F Transport ikke overraskende været meget aktiv i forbindelse med Ubers aktiviteter i København. En detaljeret gennemgang heraf vil dog falde uden for denne artikels rammer.

\section{Arbejdsgiverorganisationerne}

Mens LO og andre faglige organisationer har været meget aktive i debatten om deleøkonomi, har arbejdsgiverorganisationerne været mere tilbageholdende med at engagere sig i problemstillinger relateret til platformsøkonomien. For eksempel har hjemmesiden for Dansk Arbejdsgiverforening (DA) kun ét dokument relateret til deleøkonomi. Det er et kort svar på en høring om en meddelelse fra EU-Kommissionen om deleøkonomi fra 16. juni 2016. Det vigtigste budskab er, at den eksisterende lovgivning er tilstrækkelig til at håndtere udfordringerne fra deleøkonomien, når det kommer til ansættelsesforhold. Der er derfor ikke behov for yderligere initiativer. Dansk Industri har nogle referencer til deleøkonomi som led i sin strategi i forhold til miljøspørgsmål og den cirkulære økonomi (Dansk Industri, 2015), men ingen omfattende analyse eller politiske erklæringer. Dansk Erhverv, hvis medlemmer består af virksomheder, der hovedsageligt er orienteret mod hjemmemarkedet, har udgivet en kort analyse af begrebet deleøkonomi og en undersøgelse om brugen af primært Uber og Airbnb (Dansk Erhverv, 2015). Organisationen har også ved en række lejligheder givet udtryk for en positiv holdning til aktiviteter i deleøkonomi, men samtidig påpeget behovet for fair konkurrence, herunder overholdelse af nationale skattelovgivning.

De mest kritiske røster mod aktiviteter i deleøkonomi er - ikke overraskende - blevet rejst af de erhvervsorganisationer, som repræsenterer virksomheder, der er mest direkte berørt af de nuværende store platformsvirksomheder, især Uber og Airbnb. Således har Dansk Taxi Råd anlagt en kritisk holdning til Uber og samtidig opfordret til en modernisering og liberalisering af de komplicerede love, der aktuelt regulerer taxavirksomhederne. Hovedargumentet er således, at der bør skabes lige vilkår, hvor platformbaserede tjenester skal konkurrere med andre udbydere af transporttjenester på lige vilkår. Her er beskyttelse af kunderne og overholdelse af lovgivningen centrale emner. Sammen med andre arbejdsgiverorganisationer på taxa-området har Dansk Taxi Råd udformet et forslag til reform, som blev sendt til transportministeren i oktober 2015 (Dansk Taxi Råd m.fl., 2015). Tilsvarende har den største arbejdsgiverorganisation for hotel-, restaurant- og turisme-sektoren HORESTA kritiseret Airbnb for unfair konkurrence og opfordret til en strammere kontrol med skattepligtige indkomster fra 
de personer, der udlejer deres hjem gennem Airbnb (Horesta, 2016).

\section{Regeringen}

Som allerede nævnt i indledningen har den nuværende danske liberale regering udtrykt sig positivt om platformsøkonomien og annonceret en samlet strategi på området, som skulle offentliggøres i efteråret 2016, men i skrivende stund endnu ikke er blevet det. Derudover har den seneste langsigtede vækststrategi fra regeringen offentliggjort i august 2016 et afsnit om deleøkonomi (Regeringen 2016, 37-38). Her nævner regeringen igen, at en mere omfattende strategi vil blive offentliggjort senere i efteråret. Strategien skal sikre en mere gennemsigtig ramme på generelle områder som beskatning og forbrugerbeskyttelse. Derudover nævnes følgende mere specifikke punkter:

- Regeringen vil øge det eksisterende skattefradrag i forbindelse med udlejning af helårshuse og værelser med $10.000 \mathrm{kr}$. Fradraget for udlejning af sommerhuse vil desuden blive øget med 5.000 kr. Det ekstra fradrag er betinget af indberetning af skattepligtig indkomst til skattemyndighederne gennem et udlejningsbureau eller en digital platform.

- Desuden vil regeringen undersøge muligheden for at indføre et generelt skattemæssigt bundfradrag for aktiviteter i deleøkonomien for at øge incitamentet til at deltage i det. Igen vil dette være betinget af 'automatisk' rapportering til skattemyndighederne via en digital platform.

- For at understøtte udbredelsen af indberetningsløsningen søges indgåelse af frivillige aftaler med deleøkonomiske platforme om at bruge den digitale indberetningsløsning, og der gennemføres en markedsføringsindsats over for borgerne, deleøkonomiske platforme m.v.

- Privatpersoners øgede brug af digital betaling giver også en ny mulighed for at skabe en nem digital vej til indberetning til skattemyndighederne. En dialog med den finansielle sektor vil blive indledt med henblik på at integrere rapporteringsløsninger i eksisterende betalingstjenester, for eksempel til betaling for ydelser mellem privatpersoner.

- Regeringens fokus synes på nuværende tidspunkt næsten udelukkende at være på spørgsmål af beskatning. Hvorvidt den endelige strategi vil være mere omfattende eller visionær er i skrivende stund uvist.

\section{Konklusion}

Som i mange andre lande er spørgsmålet om 'deleøkonomi' eller 'platformsøkonomi' hurtigt kommet til tops på den offentlige dagsorden, både målt på mediernes opmærksomhed og interessen fra de politiske aktører.

Alligevel er vores viden om både indholdet og omfanget af aktiviteterne i platformsøkonomien stadig begrænset. Dette er i høj grad forårsaget af uklarheden i begrebsdannelsen på området og af de mange forskelligartede aktiviteter, som det rummer. I denne artikel har vi anlagt et mere eksplorativt perspektiv, hvor vi har søgt at skabe overblik over de arbejdsmarkedsrelaterede aktiviteter i den danske platformsøkonomi. Med afsæt i denne viden har vi diskuteret udfordringerne ved denne arbejdsform med Standings forståelse af prekariatet i baghovedet. Men, fordi vores viden fortsat er begrænset, må vurderingerne af konsekvenserne af platformsøkonomien også i nogen grad blive spekulative.

I artiklen har vi identificeret i omegnen 
af 10 platforme, der er relateret til direkte beskæftigelse, og typen af arbejde på platformene beskrev vi ud fra to parametre (lokal/global tilstedeværelse og færdighedsniveauet). Samtidig indkredsede vi, at omfanget af beskæftigelsen på platformene fortsat er lille i omfang baseret på vores viden om antallet af opgaver og brugere på platformene. På trods af dette er der dog ingen tvivl om, som vi også er inde på i analysen, at platformene helt overvejende tilbyder mere usikre eller prekære arbejdsvilkår end på det almindelige arbejdsmarked. Det gælder både med hensyn til ansættelsessikkerhed, løn og andre traditionelle lønmodtagerrettigheder og rettigheder til sociale ydelser. En hovedproblemstilling i denne forbindelse er, at platformene udfordrer det sædvanlige arbejdsgiverbegreb og skellet mellem lønmodtager og selvstændig beskæftigelse. Disse problemstillinger har også været kendt, før platformene gjorde deres indtog, men deres hurtige fremvækst og især synligheden af Ubers aktiviteter har sat udfordringerne på spidsen, selv om platformenes aktiviteter målt i forhold til den samlede beskæftigelse stadig er af begrænset betydning.

Med afsæt i den valgte analyseramme fra Standing, kan man derfor ikke, i en dansk kontekst, tale om fremvæksten af en ny prekær klasse, der udelukkende eller over- vejende arbejder gennem de digitale platforme. Men, der lader dog til at være hæftet usikkerhed til beskæftigelsen på platformene, som har en vis lighed med Standings begreb om 'denizens', vi redegjorde for tidligere, hvor arbejdet er kendetegnet ved færre rettigheder end det arbejde, der er på det traditionelle, offline arbejdsmarked.

På trods af det politiske fokus på problemet, som vi også behandler i artiklen, har udviklingen i Danmark endnu ikke i væsentligt omfang ført nye politikforslag eller konkret lovgivning med sig. Det samme er tilfældet i de øvrige nordiske lande og på EU-niveauet. Flere politiske aktører, herunder arbejdsmarkedets parter og en antal erhvervsorganisationer, har opfordret til indgreb, der skaber mere lige fælles konkurrencevilkår for traditionelle virksomheder og de nye platformsbaserede aktiviteter. Mest aktivitet finder man hos LO-fagbevægelsen og hos de erhvervsorganisationer, som direkte er berørt af de store platformsoperatører som Uber og Airbnb. Andre aktører synes i nogen grad at tøve, måske fordi regulering af platformsøkonomien, på grund af dens uklare rollefordeling mellem de involverede parter, dens mangeartede aktiviteter og dens ofte grænseoverskridende karakter, byder på betydelige nye udfordringer for udformningen af en national regulering. 


\section{Noter}

1 Det kan indskydes, at den internationale debat rummer en lang række andre betegnelser for fænomenet som f.eks. 'Peer economy'; 'Collaborative economy' (De Groen \& Maselli 2016); Collaborative consumption (Botsman 2013) 'Circular Economy'; 'Green economy'; 'Cradle-to-Cradle'; 'Gig economy'; 'Shared capitalism'; 'Sharing economy'; 'On-demand economy'; 'Hippienomics'; osv. Det vil falde udenfor denne artikels rammer med en nærmere gennemgang heraf.

2 Endvidere har et enkelt dansk studie undersøgt, hvordan forskellige arbejdsmarkedsrelevante aktører (regeringer, fagforeninger og

\section{REFERENCER}

Andersen, Søren Kaj \& Rasmus Karkov (2011): Vikarer indenfor og udenfor den danske model, i Larsen, Trine P. (red.): Insidere og outsidere - den danske models roekkevidde, København, DJØF forlaget.

BAT-Kartellet (2004): Vikarer og "arme og ben" $i$ bygge- og anloegsbranchen - et debatoploeg, København, BAT-kartellet.

Botsman, Rachel (2013): The Sharing Economy lacks a shared definition, artikel 5. Januar 2017 på: http://www.fastcoexist.com/3022028/ the-sharing-economy-lacks-a-shared-definition.

Christiansen, Jakob Haugaard (2016): Fynske taxier afventer Uber-sag, artikel i Fyens Stiftstidende 30. maj 2016.

CEVEA (2015): Digitale trends og det danske arbejdsmarked, København, CEVEA \& HK.

Dagnino, Emanuele (2016): Work in the Sharing Economy. The position of the EU Commission, ADAPT.it \& CIETT.

Dalberg Research (2014): Analyse af barrierer og udviklingsmuligheder for peer-to-peer virksomheder i Danmark, København, Dalberg Research for Erhvervsstyrelsen.

Dansk Erhverv (2015): Deleøkonomien på fremmarch, København, Dansk Erhverv.

Dansk Industri (2015): DI's miljø og ressourcepolitik, København, Dansk Industri. arbejdsgiverorganisationer) i hhv. Danmark, Sverige og Tyskland har reageret på stigende digitalisering af arbejdet indenfor privat service (Ilsøe 2017). Her var arbejdet på de digitale platforme dog ikke hovedfokus, men i analysen fremgår der korte beskrivelser af reaktioner og initiativer hos disse aktører.

3 I et kommende forskningsprojekt vil der blive udført mere selvstændig empiriindsamling $\mathrm{fx}$ i form af spørgeskema- og interviewundersøgelser, som bygger ovenpå den viden vi har opnået ved at studere de digitale platforme samt medieomtalen af dem.

Dansk Taxi Råd m.fl. (2015): Revision af taxiloven - brancheopfordring, København, offentligt brev til Folketinget Transport- og Bygningsministeren 30. oktober 2015.

De Groen, Willem Pieter \& Ilara Maselli (2016): The impact of the collaborative economy on the labour market, CEPS Special Report Nr. 138, Bruxelles, CEPS.

De Groen, Willem Pieter, Ilara Maselli \& Brian Fabo (2016), The Digital Market for Local Services: A one- night stand for workers?, CEPS Special Report Nr. 133, Bruxelles, CEPS.

Demary, Vera (2014): Competition in the Sharing Economy, IW Policy Paper Nr. 19, 2015, Køln, Institut der Deutschen Wirtschaft.

Dokko, Jane m.fl. (2015): Workers and the Online Gig Economy. A Hamilton Project Framing Paper, Brookings, The Hamilton Project.

Horesta (2016): Ny rapport: Behov for regulering af Airbnb. Nyhed på Horestas website: http:// www.horesta.dk/da-DK/Nyheder\%20og\%20 Politik/Nyheder/Nyhedsarkiv/2016/12/ Ny\%20rapport\%20Behov\%20for\%20regulering\%20af\%20Airbnb

Huws, Ursula, Niel H. Spencer \& Simon Joyce (2016): Crowd Work in Europe, FEPS Studies.

Ilsøe, Anna (2017): Digitalizing service work social partner responses in Denmark, Sweden and Germany, i TRANSFER - European Review of Labour and Research, 2017, 23(2). 
Jesnes, Kristin m.fl. (2016). Aktører og arbeid $i$ delingsøkonomien. Delrapport, FAFO-notat 2016:23, Oslo, FAFO.

Jørgensen, Steen (2016): Inspireret af Uber. Dansk tjeneste vil hjælpe folk med at få løst opgaver i hjemmet. Artikel på mobil.nu 19. maj 2016: http://mobil.nu/it-tele/find-en-derkan-loese-hjemmets-smaaopgaver-med-nydansk-app-og-tjeneste-68273

Kalleberg, Arne (2000): Nonstandard Employment relations: part-time, temporary and contract work, i Annual Rev. Social., 2000, 26, 341-65.

Kenny, Martin \& John Zysman (2015): Choosing a Future in the Platform Economy: The Implications and Consequences of Digital Platforms, Florida, Kauffman Foundation New Entrepreneurial Growth Conference, Discussion Paper.

Larsen, Trine P \& Steen, Navrbjerg (2011): Tidsbegrænset ansatte og deltidsansatte - outsidere med rettigheder i Larsen, i Trine P. (red.): Insidere og outsidere - den danske models roekkevidde, København: DJØF forlaget.

LO (2016): Platformsøkonomi - lovgivningsmoessige udfordringer og fagbevaegelsens løsningsforslag, København, LO.

Munkøe, Malthe, Jacob Ravn \& Geert Laier Christensen (2015): Deleøkonomien på frem- march, København, Dansk Erhvervs Perspektiv 2015:21.

Nordea (2016): Deleøkonomi 2016, København, NORDEA.

Rasmussen, Stine \& Per Kongshøj Madsen (2016): Sharing economy in the Nordic countries - Country report for Denmark (unpublished).

Rasmussen, Stine m.fl. (2016): Reducing precarious work in Denmark through social dialogue. The case of Denmark (final report), Aalborg \& København, Aalborg Universitet.

Regeringen (2016): Et stoerkere Danmark - Voekst 2016, København, Regeringen.

Scheuer, Steen (2011): Atypisk ansatte på det danske arbejdsmarked, LO-dokumentation Nr. 1, København: LO.

Service Cluster Denmark, DEA \& Dansk Design Center (2015): Your business in the We-economy. Navigating the waters of the new collaborative economy, København, DEA.

Standing, Guy (2011): The precariat. A new dangerous class, London, Bloomsbury Academic.

Standing, Guy (2014): A precariat charter. From denizens to citizens, London, Bloomsbury Academic.

Stokes, Kathleen m.fl. (2014): Making sense of the UK collaborative economy, Collaborative Lab and NESTA.

Stine Rasmussen, Adjunkt, Center for Arbejdsmarkedsforskning, Institut for Statskundskab, Aalborg Universitet,

e-mail: sra@dps.aau.dk

Per Kongshøj Madsen, Professor, Center for Arbejdsmarkedsforskning, Institut for Statskundskab, Aalborg Universitet

e-mail: pkm@dps.aau.dk eller pkm@osterstrand.dk 